\title{
Simulated microgravity potentiates generation of reactive oxygen species in cells
}

\author{
Fanlei Ran ${ }^{1}$, Lili $\mathrm{An}^{2}$, Yingjun Fan ${ }^{2}$, Haiying Hang ${ }^{2 \bowtie}$, Shihua Wang ${ }^{1 凶}$ \\ ${ }^{1}$ Key Laboratory of Pathogenic Fungi and Mycotoxins of Fujian Province, Key Laboratory of Biopesticide and \\ Chemical Biology of Education Ministry, School of Life Sciences, Fujian Agriculture and Forestry University, \\ Fuzhou 350002, China \\ ${ }^{2}$ Key Laboratory for Protein and Peptide Pharmaceuticals, Institute of Biophysics, Chinese Academy of Sciences, \\ Beijing 100101, China
}

Received: 29 April 2016 / Accepted: 18 July 2016 / Published online: 7 November 2016

\begin{abstract}
Microgravity (MG) and space radiation are two major environmental factors of space environment. Ionizing radiation generates reactive oxygen species (ROS) which plays a key role in radiation-induced DNA damage. Interestingly, simulated microgravity (SMG) also increases ROS production in various cell types. Thus, it is important to detect whether SMG could potentiate ROS production induced by genotoxins including radiation, especially at a minimal level not sufficient to induce detectable ROS. In this study, we treated mouse embryonic stem (MES) cells with $\mathrm{H}_{2} \mathrm{O}_{2}$ and SMG for $24 \mathrm{~h}$. The concentration of $\mathrm{H}_{2} \mathrm{O}_{2}$ used was within $30 \mu \mathrm{mol} / \mathrm{L}$ at which intracellular ROS was the same as that in untreated cells. Exposure of cells to SMG for $24 \mathrm{~h}$ did not induce significantly higher levels of intracellular ROS than that of control cells either. Simultaneous exposure of cells to both SMG- and $\mathrm{H}_{2} \mathrm{O}_{2}$ induced ROS and apoptosis in MES cells. Although incubation in medium containing 5 or $30 \mu \mathrm{mol} / \mathrm{L}$ $\mathrm{H}_{2} \mathrm{O}_{2}$ induced a small enhancement of DNA double-strand breaks (DSBs), the addition of SMG treatment dramatically increased DSB levels. Taken together, SMG can significantly potentiate the effects of $\mathrm{H}_{2} \mathrm{O}_{2}$ at a low concentration that induce a small or negligible change in cells on ROS, apoptosis, and DNA damage. The results were discussed in relation to the combined effects of space radiation and MG on human body in this study.
\end{abstract}

Keywords $\mathrm{H}_{2} \mathrm{O}_{2}$, SMG, ROS production, DNA damage, Apoptosis

\section{INTRODUCTION}

For manned space exploration, it is urgent to investigate the effects of the space environment on human health. Of all the known space environmental factors, microgravity (MG) and space radiation have been recognized as the two major environmental factors. Because of the cost effectiveness and limited access to space flight, simulated microgravity (SMG) on Earth has been widely

Fanlei Ran and Lili An have contributed equally to this work.

$\bowtie$ Correspondence: hh91@ibp.ac.cn (H. Hang), wshyyl@sina.com (S. Wang) used in space life research. The integrity of genomic DNA is important for normal physiological functions of cells and DNA damage is related to many diseases such as cancer and aging among others (Lombard et al. 2005; Hoeijmakers 2009). Thus, it is important to investigate the effects of space environment on cellular DNA damage.

It is well known that ionizing radiation (IR) generates reactive oxygen species (ROS) which plays important roles in DNA damage induced by radiation (Tominaga et al. 2004). Interestingly, several lines of evidence showed that SMG increased ROS production in some cell types, such as the PC12 cells, SH-SY5Y cells, and MEF 
cells (Wang et al. 2009; Qu et al. 2010; Li et al. 2015). It has been reported that SMG delayed the rejoining of double-strand breaks (DSBs) induced by IR and increased the genotoxic effects of IR (Mognato et al. 2009). Mognato et al. also reported that SMG treatment decreased the surviving fraction and increased the HPRT mutant frequency in human peripheral blood lymphocytes (Mognato and Celotti 2005). We asked whether SMG could potentiate ROS production and DNA damage induced by space radiation. In the real space environment, space radiation and microgravity act continuously on the body together. Owing to the limitation of the experimental conditions, ionizing radiation and SMG treatment have to be separated into two processes. Thus, in this study, we used $\mathrm{H}_{2} \mathrm{O}_{2}$ instead of radiation and SMG at the same time and investigated whether simulated microgravity could potentiate ROS generation, DNA damage, and apoptosis. Since radiation level inside a space shuttle or a satellite may be too low to induce ROS, we are particularly interested in the following question: when SMG itself cannot induce ROS in a model cell, and the concentration of $\mathrm{H}_{2} \mathrm{O}_{2}$ is kept low so ROS cannot be induced by $\mathrm{H}_{2} \mathrm{O}_{2}$ under $1 \mathrm{G}$, whether SMG can induce ROS in the model cell treated with the low concentration of $\mathrm{H}_{2} \mathrm{O}_{2}$. So far, there have been no reports on the combined effects of SMG and low concentration of $\mathrm{H}_{2} \mathrm{O}_{2}$ on ROS production and DNA damage. In this study, we found that SMG exposure for $24 \mathrm{~h}$ or $\mathrm{H}_{2} \mathrm{O}_{2}$ treatment at a concentration below $30 \mu \mathrm{mol} / \mathrm{L}$ for $24 \mathrm{~h}$ under $1 \mathrm{G}$ could not enhance ROS above untreated mouse embryonic stem (MES) cells, but the combination of these two treatments significantly induced ROS in MES cells. SMG also potentiated the effects of $\mathrm{H}_{2} \mathrm{O}_{2}$ on DNA damage and apoptosis. The results were discussed in relation to the combined effect of space radiation and MG on human body in this study.

\section{RESULTS}

\section{Combined effects of SMG and $\mathrm{H}_{2} \mathrm{O}_{2}$ on ROS production in wild-type MES cells}

To investigate the combined effects of SMG and $\mathrm{H}_{2} \mathrm{O}_{2}$ in ROS production in wild-type MES cells, $\mathrm{H}_{2} \mathrm{O}_{2}$ at the indicated concentrations was added to the media of the cells under $1 \mathrm{G}$ and SMG, respectively, and the intracellular ROS level was analyzed by $2^{\prime}, 7^{\prime} 2$ dichlorodihydrofluorescein diacetate (DCF-DA) staining. As shown in Fig. 1, the relative DCF fluorescence was slightly higher in the cells cultured under SMG than that in the cells cultured under $1 \mathrm{G}$. However, the difference was not

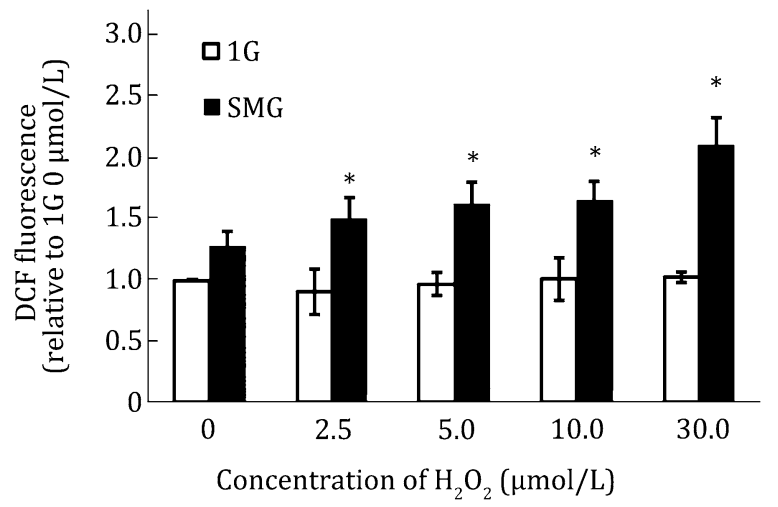

Fig. 1 Effects of SMG and $\mathrm{H}_{2} \mathrm{O}_{2}$ treatment on ROS production in wild-type MES cells. Wild-type MES cells were cultured under $1 \mathrm{G}$ or SMG for $24 \mathrm{~h}$ and treated with $\mathrm{H}_{2} \mathrm{O}_{2}$ at the indicated concentrations at the same time. Then the ROS activity was analyzed with flow cytometry. The experiments were performed thrice independently. The data are shown as mean \pm SD. Student's $t$ test, ${ }^{*} p<0.05$

statistically significant. This was consistent with our previous report ( $\mathrm{Li}$ et al. 2015). In the cells cultured under $1 \mathrm{G}$, treatment of the cells with low concentrations of $\mathrm{H}_{2} \mathrm{O}_{2}$ (from 2.5 to $30 \mu \mathrm{mol} / \mathrm{L}$ ) did not alter the intracellular ROS production significantly either. Interestingly, at each indicated concentration of $\mathrm{H}_{2} \mathrm{O}_{2}$, we observed significantly increased intracellular ROS production in the cells cultured under SMG than that in the cells cultured under $1 \mathrm{G}$. These results indicate that SMG triggers ROS production in MES cells incubated in medium containing $\mathrm{H}_{2} \mathrm{O}_{2}$ at the concentration of $30 \mu \mathrm{mol} / \mathrm{L}$ or lower.

\section{Potentiation of SMG to the effect of $\mathrm{H}_{2} \mathrm{O}_{2}$ on DNA damage}

ROS can inflict DNA lesions (Schieber and Chandel 2014). To investigate the combined effect of SMG and $\mathrm{H}_{2} \mathrm{O}_{2}$ on DNA damage in MES cells, $\mathrm{H}_{2} \mathrm{O}_{2}$ was added to the media of the cells cultured under SMG and $1 \mathrm{G}$, respectively, at the indicated concentrations, and the DNA damage was analyzed by comet assay. The comet assay is a sensitive method for measuring DNA lesions in single cells. The amount of DNA migration under electric potential indicates the amount of DNA damage in the cell. As shown in Fig. 2, there was no significant difference in DNA damage between the cells cultured under SMG and those cultured under $1 \mathrm{G}$, which was consistent with our previous report ( $\mathrm{Li}$ et al. 2015). Although 5 or $30 \mu \mathrm{mol} / \mathrm{L}_{2} \mathrm{O}_{2}$ did not enhance intracellular ROS levels, it was able to cause higher levels of DNA damage under 1G (Fig. 2B). This elevated level of DNA lesions was small but statistically significant (data not shown). In contrast, when treated with 5 or 
A

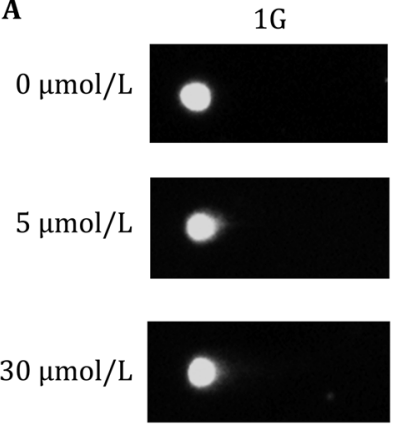

B

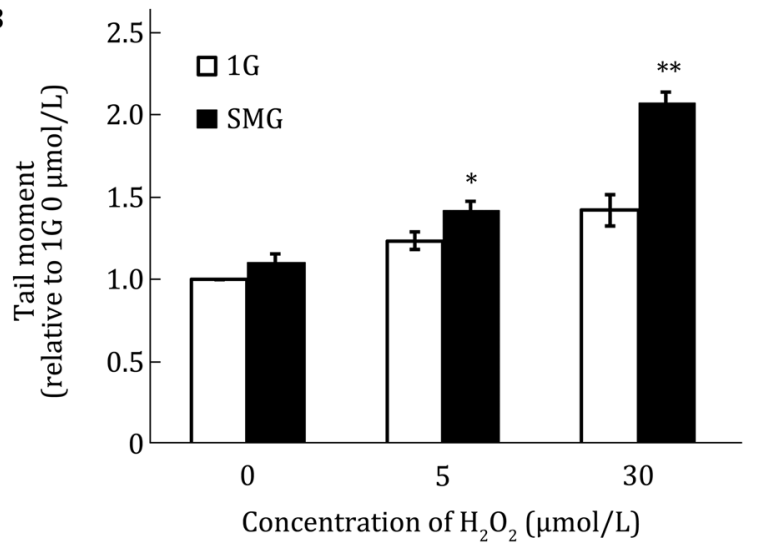

Fig. 2 Effects of SMG and $\mathrm{H}_{2} \mathrm{O}_{2}$ treatment on DNA damage in wild-type MES cells. Wild-type MES cells were cultured under $1 \mathrm{G}$ or SMG for $24 \mathrm{~h}$ and treated with $\mathrm{H}_{2} \mathrm{O}_{2}$ at the indicated concentrations at the same time. Then DNA damage was evaluated using neutral comet assay. The representative results of comet assay are shown in $\mathbf{A}$ and the quantitative comparison of comet tail moments are shown in B. At least 50 cells were scored for analysis of the comet tail moment. The experiments were performed thrice independently. The data are shown as mean \pm SD. Student's $t$ test, ${ }^{*} p<0.05,{ }^{* *} p<0.01$

$30 \mu \mathrm{mol} / \mathrm{L} \mathrm{H}_{2} \mathrm{O}_{2}$, the relative tail moment of the cells cultured under SMG was significantly higher than that cultured under $1 \mathrm{G}$. These results indicate that SMG potentiates the effect of $\mathrm{H}_{2} \mathrm{O}_{2}$ on DNA damage.

\section{NAC significantly suppresses DNA damage in MES cells treated with both SMG and $\mathrm{H}_{2} \mathrm{O}_{2}$}

$\mathrm{N}$-acetylcysteine (NAC) is a widely used ROS scavenger (Dhouib et al. 2016). As shown in Fig. 3, $1 \mathrm{mmol} / \mathrm{L}$ NAC effectively suppressed ROS induced by the combined treatments of $\mathrm{H}_{2} \mathrm{O}_{2}$ and SMG. $1 \mathrm{mmol} / \mathrm{L} \mathrm{NAC}$ also effectively suppressed DNA damage induced by the combined treatments of $\mathrm{H}_{2} \mathrm{O}_{2}$ and SMG (Fig. 4), suggesting that the DNA lesions inflicted by the combined treatments of $\mathrm{H}_{2} \mathrm{O}_{2}$ and SMG are mediated by ROS production in cells.

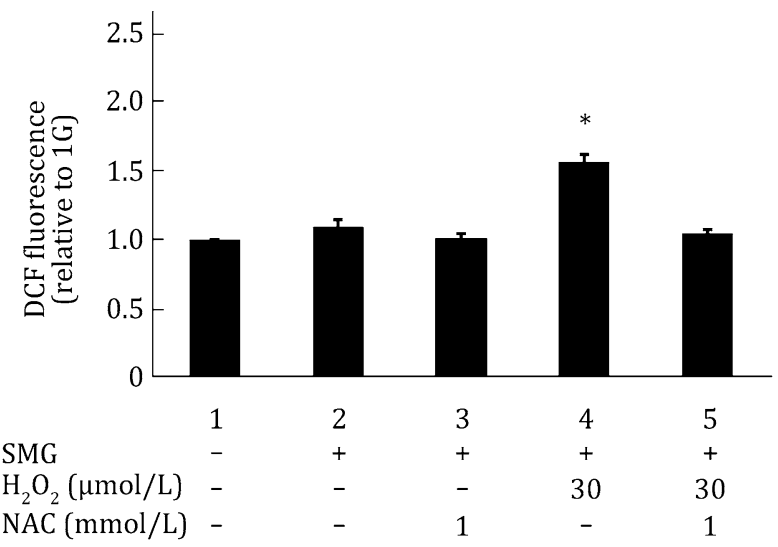

Fig. 3 NAC significantly reduces ROS production in MES cells treated with both $\mathrm{SMG}$ and $\mathrm{H}_{2} \mathrm{O}_{2}$. Flow cytometric analysis of ROS activity in wild-type MES cells. Column 1 wild-type MES cells cultured under $1 \mathrm{G}$ without any treatment; Column 2 wild-type MES cells cultured under SMG without any treatment; Column 3 wild-type MES cells maintained under SMG and treated with $1 \mathrm{mmol} / \mathrm{L}$ NAC; Column 4 wild-type MES cells cultured under SMG and treated with $30 \mu \mathrm{mol} / \mathrm{L} \mathrm{H}_{2} \mathrm{O}_{2}$; Column 5 wild-type MES cells cultured under SMG and treated with $30 \mu \mathrm{mol} / \mathrm{L} \mathrm{H}_{2} \mathrm{O}_{2}$ as well as $1 \mathrm{mmol} / \mathrm{L}$ NAC. The experiments were performed thrice independently. The data are shown as mean \pm SD. Student's $t$ test, ${ }^{*} p<0.05$ compared with Column 1

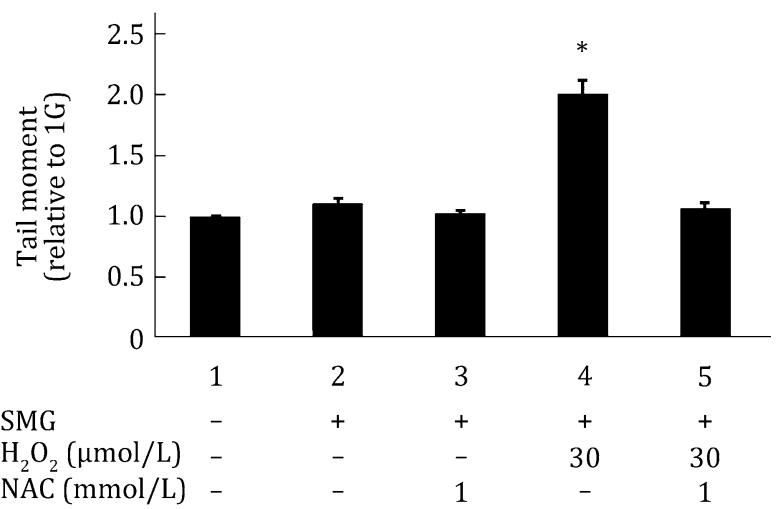

Fig. 4 NAC significantly reduces DNA damage in MES cells treated with both SMG and $\mathrm{H}_{2} \mathrm{O}_{2}$. DNA damage was assayed by neutral comet assay in wild-type MES cells. Column 1 wild-type MES cells cultured under $1 \mathrm{G}$ without any treatment; Column 2 wild-type MES cells cultured under SMG without any treatment; Column 3 wild-type MES cells cultured under SMG and treated with $1 \mathrm{mmol} / \mathrm{L}$ NAC; Column 4 wild-type MES cells cultured under SMG and treated with $30 \mu \mathrm{mol} / \mathrm{L}_{2} \mathrm{O}_{2}$; Column 5 wild-type MES cells cultured under SMG and treated with $30 \mu \mathrm{mol} / \mathrm{L}_{2} \mathrm{O}_{2}$ as well as $1 \mathrm{mmol} / \mathrm{L} \mathrm{NAC}$. The experiments were performed thrice independently. The data are shown as mean \pm SD. Student's $t$ test, ${ }^{*} p<0.05$ compared with Column 1

\section{NAC significantly reduces apoptosis in MES cells treated with both SMG and $\mathrm{H}_{2} \mathrm{O}_{2}$}

As shown above, SMG potentiated the effect of $\mathrm{H}_{2} \mathrm{O}_{2}$ on DNA damage in MES cells, and DNA damage leads to apoptosis (Zhang et al. 2016). Previously we observed 
that SMG itself was unable to induce apoptosis in wildtype MES cells (Li et al. 2015).We asked whether SMG could potentiate the effect of $\mathrm{H}_{2} \mathrm{O}_{2}$ on apoptosis in MES cells. As shown in Fig. 5, SMG triggered apoptosis in MES cells treated with $30 \mathrm{mmol} / \mathrm{L} \mathrm{H}_{2} \mathrm{O}_{2}$ (Fig. 5). NAC treatment effectively reversed the increased apoptosis. Our results indicate that enhanced ROS mediates apoptosis induced by the combined treatments of $\mathrm{H}_{2} \mathrm{O}_{2}$ and SMG.

\section{DISCUSSION}

In this study, we found that SMG exposure alone or $\mathrm{H}_{2} \mathrm{O}_{2}$ treatment at a low concentration alone could not enhance ROS production in MES cells. However, the combination of these two treatments significantly induced ROS production (Fig. 2). SMG also potentiated the effects of $\mathrm{H}_{2} \mathrm{O}_{2}$ on DNA damage and apoptosis. Furthermore, ROS scavenger NAC could inverse these effects in MES cells treated with both SMG and $\mathrm{H}_{2} \mathrm{O}_{2}$ (Figs. 4 and 5).

In mammalian cells, there is a balance of ROS production and scavenging (Aon et al. 2010). A small increase in ROS levels only activates signaling pathways to initiate biological processes, but high levels of ROS also result in damage to DNA, protein, or lipids (Schieber and Chandel 2014). In this study, treatment of the MES cells cultured under $1 \mathrm{G}$ with $30 \mu \mathrm{mol} / \mathrm{L}_{2} \mathrm{O}_{2}$ did not significantly alter the intracellular ROS production.

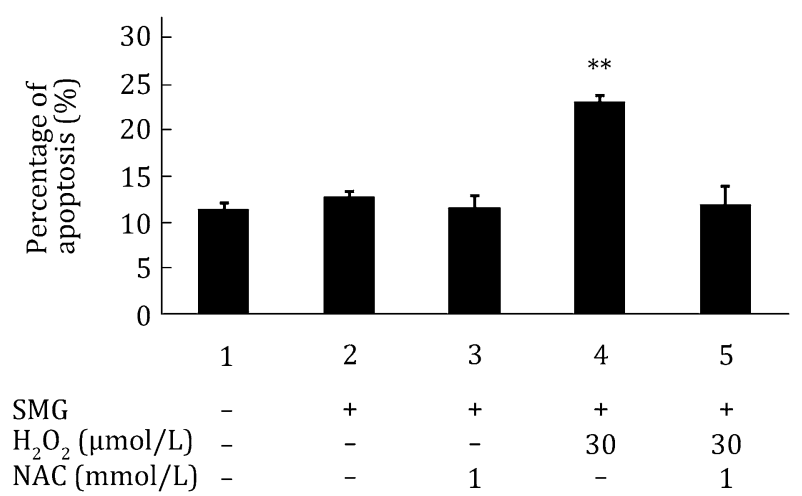

Fig. 5 NAC significantly reduces apoptosis in MES cells treated with both $\mathrm{SMG}$ and $\mathrm{H}_{2} \mathrm{O}_{2}$. Flow cytometric analysis of apoptosis in wild-type MES cells. Column 1 wild-type MES cells cultured under $1 \mathrm{G}$ without any treatment; Column 2 wild-type MES cells cultured under SMG without any treatment; Column 3 wild-type MES cells cultured under SMG and treated with $1 \mathrm{mmol} / \mathrm{L} \mathrm{NAC}$; Column 4 wild-type MES cells cultured under SMG and treated with $30 \mu \mathrm{mol} / \mathrm{L}_{2} \mathrm{O}_{2}$; Column 5 wild-type MES cells cultured under SMG and treated with $30 \mu \mathrm{mol} / \mathrm{L} \mathrm{H}_{2} \mathrm{O}_{2}$ as well as $1 \mathrm{mmol} / \mathrm{L} \mathrm{NAC}$. The experiments were performed thrice independently. The data are shown as mean \pm SD. Student's $t$ test, ${ }^{* *} p<0.01$ compared with Column 1
Consistently, we did not observe increased apoptosis in these cells. It seems that cultured under 1G, MES cells could effectively scavenge the increased ROS induced by $30 \mu \mathrm{mol} / \mathrm{L}_{2} \mathrm{O}_{2}$, avoiding the damage of the oxidative stress to the cells. Although 5 or $30 \mu \mathrm{mol} / \mathrm{L}_{2} \mathrm{O}_{2}$ did not enhance intracellular ROS levels, it was able to cause slightly but also significantly higher levels of DNA damage than that under $1 \mathrm{G}$ (Fig. 2B). It seems that $\mathrm{H}_{2} \mathrm{O}_{2}$ as low as $5 \mu \mathrm{mol} / \mathrm{L}$ could induce increased DNA damage before it was scavenged by the cells.

Wang et al. reported that SMG increased the amount of ROS in rat PC12 cells (Wang et al. 2009). Previously, we observed significant SMG-induced ROS production and DNA damage in $\mathrm{Rad}^{-/-}$MES but not in wild-type MES cells (Li et al. 2015). In this study, SMG treatment potentiated $30 \mu \mathrm{mol} / \mathrm{L}_{2} \mathrm{O}_{2}$.induced ROS production, as well as DNA damage and apoptosis in wild-type MES cells, indicating the synergistic effects of SMG and $\mathrm{H}_{2} \mathrm{O}_{2}$. Altogether, these results indicate that SMG is a weak genotoxic stress and could break the balance of ROS production and scavenging under the stress of low dose of $\mathrm{H}_{2} \mathrm{O}_{2}$. However, the precise mechanisms need further investigation.

In addition to microgravity, space radiation is another key detrimental factor in space environment. It has been reported that the superoxide increased by $16.5 \%$ after $15 \mathrm{~min}$ of 5 cGy radiation in A549 cells (Chen et al. 2015). Manganese superoxide dismutase $\left(\mathrm{SOD}_{2}\right)$ could be induced by IR with the dose as low as 2 cGy (Veeraraghavan et al. 2011). To our knowledge, there is no report on ROS production induced by IR at the doses lower than 2 cGy. It should be noted that at orbital altitudes near that of the International Space Station, the dose-equivalent to the astronauts is about $0.3 \mathrm{~Sv}$ per year (an absorbed dose of 1 Gy by alpha particles will lead to an equivalent dose of $20 \mathrm{~Sv}$ ) (Thirsk et al. 2009), which means the effects of space radiation alone on ROS production may be not significant. However, we have shown that SMG potentiated ROS production induced by low concentrations of $\mathrm{H}_{2} \mathrm{O}_{2}$. Thus in the real space environment, microgravity may also potentiate space radiation-induced ROS production and DNA damage, which should be tested in the real space experiments. Furthermore, during manned space travel, the astronauts experience stressful conditions such as loneliness, tension, and lack of exercise. These may also lead to increased ROS levels in the astronauts. Thus whether SMG potentiates ROS production induced by these conditions deserves further investigation.

NAC is widely used in ROS scavenging (Dhouib et al. 2016). Here, we found that NAC could effectively suppress $\mathrm{SMG}$ and $\mathrm{H}_{2} \mathrm{O}_{2}$-induced ROS production, DNA damage as well as apoptosis in MES cells. Wang et al. 
also reported the protective effects of NAC on ROS production and cell senescence under SMG treatment (Wang et al. 2009). Qu et al. showed that antioxidants, isorhamnetin and luteolin, could protect neuroblastoma SH-SY5Y cells against microgravity-induced oxidative stress (Qu et al. 2010). These results indicate that antioxidants such as NAC might be used in the protection of ROS stress induced by the combined effects of SMG and other factors of space environment, which may provide valuable strategy for health protection in manned space exploration.

\section{MATERIALS AND METHODS}

\section{D-clinostat}

The 3D-clinostat which was used for SMG treatment was provided by Center for Space Science and Applied Research, Chinese Academy of Sciences (Jiang et al. 2008). By employing simultaneous rotations on two axes, the 3D-clinostat can produce an environment with an average of $10^{-3} \mathrm{G}$, thus simulating microgravity conditions.

\section{Cell culture}

MES cells, originally derived from Joyner's laboratory (Auerbach et al. 2000), were cultured on gelatin-coated flasks in standard ES cell medium with leukemia inhibitory factor (LIF) according to Joyner AL without a feeder layer (Matise et al. 2000). Cells were seeded in culture flasks (Becton-Dickinson) and were maintained under $1 \mathrm{G}$ for $18 \mathrm{~h}$ so that the cells could adhere to the flasks. Then the flasks were filled with fresh medium and the air bubbles were eliminated in order to diminish turbulence and shear forces. The 3D-clinostat was placed in an incubator with an atmosphere of 95\% air $/ 5 \% \mathrm{CO}_{2}$ at $37{ }^{\circ} \mathrm{C}$. The day on which the flasks were placed on the clinostat was designated as Day 0. We did not change the culture medium during the experimental period.

The MES cells maintained under $1 \mathrm{G}$ or SMG were treated with $\mathrm{H}_{2} \mathrm{O}_{2}$ at the concentrations of $0,2.5,5,10$, and $30 \mu \mathrm{mol} / \mathrm{L}$ for $24 \mathrm{~h}$. For antioxidant treatment, the cells were also treated with ROS scavenger NAC (1 mmol/L) for $24 \mathrm{~h}$.

\section{Apoptosis assays}

MES cells were seeded at $5 \times 10^{5}$ cells per $25 \mathrm{~cm}^{2}$ culture flask. After treatment, the cells were trypsinized with $0.1 \%$ trypsin at $37{ }^{\circ} \mathrm{C}$ (Sigma), then washed twice with cold PBS, and resuspended in $1 \times$ binding buffer at $1 \times 10^{6}$ cells $/ \mathrm{mL}$. After that, the cells were stained with Alexa Fluor ${ }^{\circledR} 488$ annexin V and PI (Invitrogen) at room temperature for $15 \mathrm{~min}$ for flow cytometric analysis.

\section{Comet assay}

Comet assay was performed according to the protocol of Singh et al. (1988) with minor modifications. Firstly, we pre-coated the slides with a thin layer of $1 \%$ normal melting agarose. Secondly, the cells were harvested and resuspended at a concentration of $5 \times 10^{5}$ cells $/ \mathrm{mL}$. $20 \mu \mathrm{L}$ of each suspension was added to $80 \mu \mathrm{L}$ of premelted $0.75 \%$ low melting agarose and the contents were pipetted onto the pre-coated slide. Thirdly, the slides were immersed in neutral lysis solution in the dark at $4{ }^{\circ} \mathrm{C}$ for $2 \mathrm{~h}$. For unwinding of the DNA, the slides were immersed in $1 \times$ TBE buffer in the dark at $4{ }^{\circ} \mathrm{C}$ for $30 \mathrm{~min}$. After that, the slides were exposed to $\sim 0.74 \mathrm{~V} / \mathrm{cm}$ for $25 \mathrm{~min}$ in the horizontal electrophoresis chamber. Following electrophoresis, we stained the slides with propidium iodine (PI). Fluorescence images were viewed with a microscope and analyzed by CASP-1.2.2 software (University of Wroclaw).

\section{ROS activity assays}

The cells were stained with $20 \mu \mathrm{mol} / \mathrm{L} 2^{\prime}, 7^{\prime}$ dichlorodihydrofluorescein diacetate (DCF-DA) (Sigma, USA), and intracellular ROS activity was examined (Shen et al. 2001). The fluorogenic probe DCF-DA is cell-permeable. It diffuses into cells and is deacetylated into the nonfluorescent DCFH by cellular esterases. While, in the presence of ROS, DCFH is rapidly oxidized to highly fluorescent DCF. The fluorescence intensity was measured by flow cytometry (FACSCalibur, Becton-Dickinson, USA) with excitation settings of $488 \mathrm{~nm}$ and emission settings of $530 \mathrm{~nm}$, respectively.

\section{Statistical analysis}

The data are shown as mean $\pm \mathrm{SD}$. The statistical significance of the difference was analyzed by the Student's $t$ test. $p<0.05$ was considered statistically significant.

$\begin{array}{ll}\text { Abbreviations } \\ \text { MG } & \text { Microgravity } \\ \text { IR } & \text { Ionizing radiation } \\ \text { ROS } & \text { Radical oxygen species } \\ \text { SMG } & \text { Simulated microgravity } \\ \text { MES } & \text { Mouse embryonic stem } \\ \text { DSB } & \text { Double-strand breaks }\end{array}$




$\begin{array}{ll}\text { DCF-DA } & 2^{\prime}, 7^{\prime} 2 \text { dichlorodihydrofluorescein diacetate } \\ \text { NAC } & \text { N-acetylcysteine } \\ \mathrm{SOD}_{2} & \text { Manganese superoxide dismutase } \\ \text { LIF } & \text { Leukemia inhibitory factor } \\ \text { PI } & \text { Propidium iodine }\end{array}$

Acknowledgments This work was supported by the "Strategic Priority Research Program" of the Chinese Academy of Sciences (XDA04020202-13 and XDA04020413) and the National Natural Science Foundation of China (31370792 and 11179040).

\section{Compliance with ethical standards}

Conflict of interest Fanlei Ran, Lili An, Yingjun Fan, Haiying Hang, and Shihua Wang declare that they have no conflict of interest.

Human and animal rights and informed consent This article does not contain any studies with human or animal subjects performed by any of the authors.

Open Access This article is distributed under the terms of the Creative Commons Attribution 4.0 International License (http:// creativecommons.org/licenses/by/4.0/), which permits unrestricted use, distribution, and reproduction in any medium, provided you give appropriate credit to the original author(s) and the source, provide a link to the Creative Commons license, and indicate if changes were made.

\section{References}

Aon MA, Cortassa S, O’Rourke B (2010) Redox-optimized ROS balance: a unifying hypothesis. Biochim Biophys Acta 1797:865-877

Auerbach W, Dunmore JH, Fairchild-Huntress V, Fang Q, Auerbach AB, Huszar D, Joyner AL (2000) Establishment and chimera analysis of $129 / \mathrm{SvEv}$ - and C57BL/6-derived mouse embryonic stem cell lines. BioTechniques, vol 29, pp 1024-1028, 1030, 1032

Chen N, Wu L, Yuan H, Wang J (2015) ROS/Autophagy/Nrf2 pathway mediated low-dose radiation induced radio-resistance in human lung adenocarcinoma A549 cell. Int J Biol Sci 11:833-844

Dhouib IE, Annabi A, Jallouli M, Elfazaa S, Lasram MM (2016) A minireview on N-acetylcysteine: an old drug with new approaches. Life Sci 151:359-363

Hoeijmakers JH (2009) DNA damage, aging, and cancer. N Engl J Med 361:1475-1485
Jiang Y, Li W, Wang L, Zhang Z, Zhang B, Wu H (2008) Several new type of clinostat. Space Med Med Eng 21:368-371

Li N, An L, Hang H (2015) Increased sensitivity of DNA damage response-deficient cells to stimulated microgravity-induced DNA lesions. PLoS One 10:e0125236

Lombard DB, Chua KF, Mostoslavsky R, Franco S, Gostissa M, Alt FW (2005) DNA repair, genome stability, and aging. Cell 120:497-512

Matise MP, Auerbach AB, Joyner AL (2000) Production of targeted embryonic stem cell clones. In: Joyner AL (ed) Gene targeting: a practical approach, 2nd edn. Oxford University Press, New York, pp 101-132

Mognato M, Celotti L (2005) Modeled microgravity affects cell survival and HPRT mutant frequency, but not the expression of DNA repair genes in human lymphocytes irradiated with ionising radiation. Mutat Res 578:417-429

Mognato M, Girardi C, Fabris S, Celotti L (2009) DNA repair in modeled microgravity: double strand break rejoining activity in human lymphocytes irradiated with gamma-rays. Mutat Res 663:32-39

Qu L, Chen H, Liu X, Bi L, Xiong J, Mao Z, Li Y (2010) Protective effects of flavonoids against oxidative stress induced by simulated microgravity in SH-SY5Y cells. Neurochem Res 35:1445-1454

Schieber M, Chandel NS (2014) ROS function in redox signaling and oxidative stress. Curr Biol 24:R453-R462

Shen YC, Chou CJ, Chiou WF, Chen CF (2001) Anti-inflammatory effects of the partially purified extract of radix Stephaniae tetrandrae: comparative studies of its active principles tetrandrine and fangchinoline on human polymorphonuclear leukocyte functions. Mol Pharmacol 60:1083-1090

Singh NP, McCoy MT, Tice RR, Schneider EL (1988) A simple technique for quantitation of low levels of DNA damage in individual cells. Exp Cell Res 175:184-191

Thirsk R, Kuipers A, Mukai C, Williams D (2009) The space-flight environment: the international space station and beyond. CMAJ 180:1216-1220

Tominaga H, Kodama S, Matsuda N, Suzuki K, Watanabe M (2004) Involvement of reactive oxygen species (ROS) in the induction of genetic instability by radiation. J Radiat Res 45:181-188

Veeraraghavan J, Natarajan M, Herman TS, Aravindan N (2011) Low-dose gamma-radiation-induced oxidative stress response in mouse brain and gut: regulation by NFkappaBMnSOD cross-signaling. Mutat Res 718:44-55

Wang J, Zhang J, Bai S, Wang G, Mu L, Sun B, Wang D, Kong Q, Liu Y, Yao X, Xu Y, Li H (2009) Simulated microgravity promotes cellular senescence via oxidant stress in rat PC12 cells. Neurochem Int 55:710-716

Zhang L, Cheng X, Gao Y, Bao J, Guan H, Lu R, Yu H, Xu Q, Sun Y (2016) Induction of ROS-independent DNA damage by curcumin leads to G2/M cell cycle arrest and apoptosis in human papillary thyroid carcinoma BCPAP cells. Food Funct $7: 315-325$ 